Provided for non-commercial research and education use. Not for reproduction, distribution or commercial use.

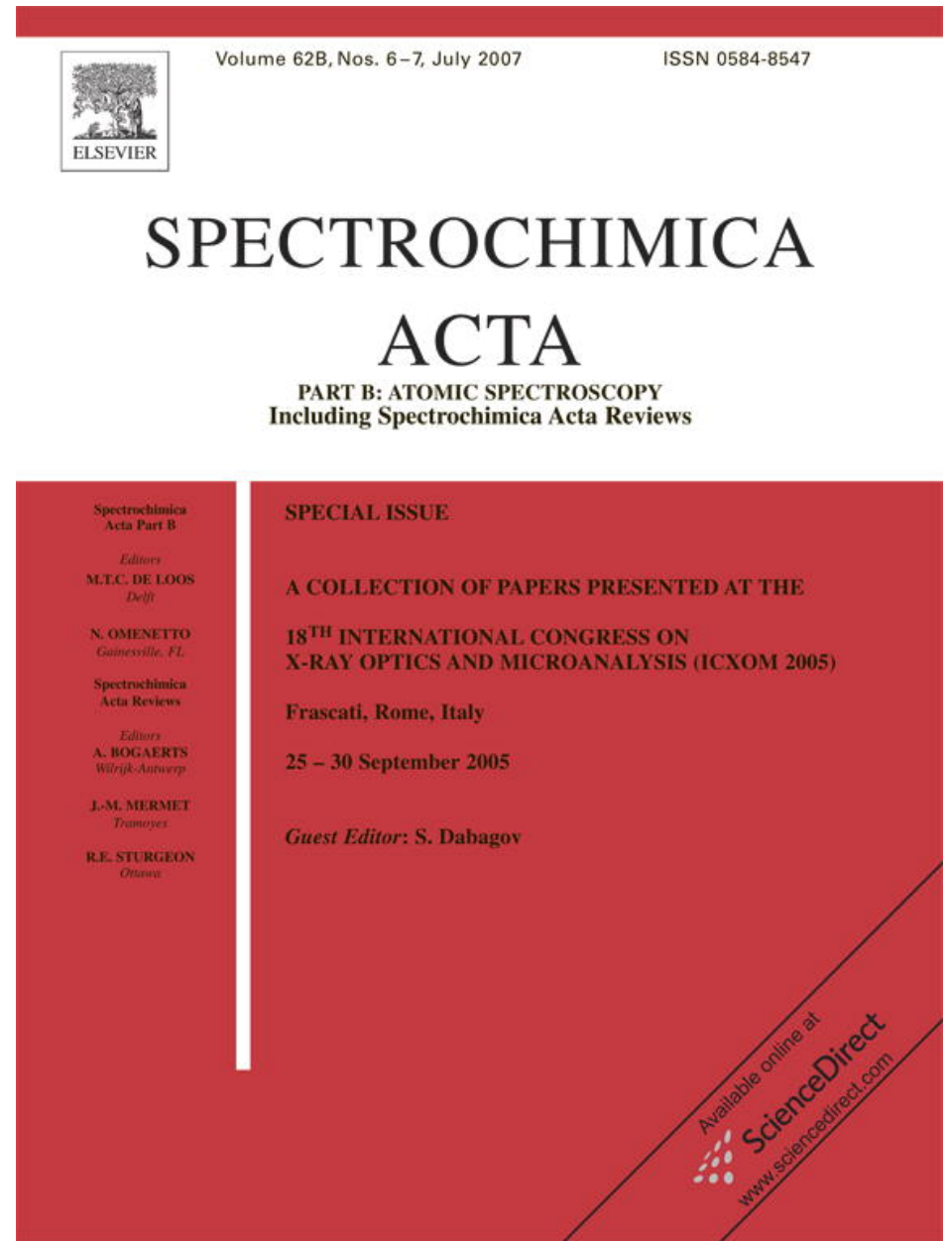

This article was published in an Elsevier journal. The attached copy

is furnished to the author for non-commercial research and education use, including for instruction at the author's institution, sharing with colleagues and providing to institution administration.

Other uses, including reproduction and distribution, or selling or licensing copies, or posting to personal, institutional or third party websites are prohibited.

In most cases authors are permitted to post their version of the article (e.g. in Word or Tex form) to their personal website or institutional repository. Authors requiring further information regarding Elsevier's archiving and manuscript policies are encouraged to visit: 


\title{
Iron, copper, zinc and bromine mapping in cirrhotic liver slices from patients with hemochromatosis studied by microscopic synchrotron radiation X-ray fluorescence analysis in continuous scanning mode ${ }^{\text {is }}$
}

\author{
W. Osterode ${ }^{\mathrm{a}, *}$, G. Falkenberg ${ }^{\mathrm{b}}$, R. Höftberger ${ }^{\mathrm{c}}$, F. Wrba ${ }^{\mathrm{d}}$ \\ ${ }^{a}$ Medizinische Universität Wien, Univ. Klinik für Innere Medizin IV, Klinische Abteilung für Arbeitsmedizin, Währinger Gürtel 18-20, A-1090 Wien, Austria \\ ${ }^{\mathrm{b}}$ Hamburger Synchrotronstrahlungslabor HASYLAB, Deutsches Elektronen-Synchrotron DESY, Germany \\ ${ }^{\mathrm{c}}$ Medizinische Universität Wien, Klinisches Institut für Neurologie, Austria \\ ${ }^{\mathrm{d}}$ Medizinische Universität Wien, Klinisches Institut für Klinische Pathologie, Austria
}

Received 1 December 2005; accepted 17 March 2007

Available online 1 April 2007

\begin{abstract}
Iron $(\mathrm{Fe})$ and copper $(\mathrm{Cu})$ are essential metals in physiological cell metabolism. While $\mathrm{Fe}$ is easy to determine biochemically in histological slices, $\mathrm{Cu}$ and zinc $\mathrm{Zn}$ ) distribution is frequently critical in confirming the presence of an overload in disturbed Fe/Cu metabolism. To analyze Fe, $\mathrm{Cu}$ and $\mathrm{Zn}$ in a near histological resolution, energy dispersive microscopic synchrotron radiation X-ray fluorescence was applied.

In normal liver tissue, after fixation and imbedding in paraffin, mean $\mathrm{Fe}, \mathrm{Cu}$ and $\mathrm{Zn}$ concentrations were $152 \pm 54,20.1 \pm 4.3 \mathrm{and} 88.919 .5 \mu \mathrm{g} / \mathrm{g}$ sample weight, respectively. No substantial, characteristic differences in their distribution were found in the two-dimensional scans. In slices from patients with hemochromatosis mean $\mathrm{Fe}, \mathrm{Cu}$ and $\mathrm{Zn}$ concentrations were $1102 \pm 539,35.9 \pm 14.6$ and $27.2 \pm 6.7 \mu \mathrm{g} / \mathrm{g}$ sample weight, respectively. Additionally, a significant decrease in phosphorus and sulphur concentrations existed. An increased $\mathrm{Cu}$ around cirrhotic regenerations nodules is mostly associated with a lymphocytic infiltration in this region. Analyzing concentrations of Fe in different regions of the samples show a clear negative dependency between $\mathrm{Fe}$ and $\mathrm{Cu}, \mathrm{Cu}$ and $\mathrm{Zn}$, but a positive one between $\mathrm{Fe}$ and $\mathrm{Zn}$.

Conclusion: With a focal beam size of $15 \mu \mathrm{m}$ in diameter a resolution of the elemental distribution was achieved which is widely comparable with stained histological slices $(20 \times$ light microscope). The analysis of simultaneous determined elements reveals metabolic differences between $\mathrm{Fe}, \mathrm{Cu}$ and $\mathrm{Zn}$ in liver tissue from patients with hemochromatosis.
\end{abstract}

(C) 2007 Elsevier B.V. All rights reserved.

Keywords: Hemochromatosis; Iron; Copper; Quantitative trace element mapping; Synchrotron radiation microscopic X-ray fluorescence

\section{Introduction}

Iron $(\mathrm{Fe})$, copper $(\mathrm{Cu})$ and zinc $(\mathrm{Zn})$ are essential metals in physiological cell metabolism. Their importance for the survival, replication and differentiation is well established $[1,2]$. Induced effects of these trace elements are dependent on one another [3-5]. Iron in excess is toxic, particularly in man, where hemochromatosis (iron overload characterized by

\footnotetext{
is This paper was presented at the "18th International Congress on X-ray Optics and Microanalysis" (ICXOM-18) held in Frascati, Rome (Italy), 25-30 September 2005, and is published in the Special Issue of Spectrochimica Acta Part B, dedicated to that conference.

* Corresponding author. Tel.: +43 140400 4701; fax: +43 14088011.

E-mail address: wolf.osterode@meduniwien.ac.at (W. Osterode).
}

hyperabsorption of dietary iron) is one of the most frequent genetic disorders [6], leading in the end-stage to liver cirrhosis. On the other hand, zinc supplementation has shown to prevent acute hepatitis by reducing copper absorption and interfering with iron [7]. Diagnosis of hemochromatosis can be made by biochemical parameters, genetically and/or histologically by liver biopsy [8]. However, while iron is relatively easy to dye for the investigation of its distribution in human tissue slices, copper staining are often not sensitive enough or the chemicals used introduce impurities which may induce misleading results $[9,10]$. The widely applied rhodanine staining for copper detection identifies free copper, but not copper bound in copper binding proteins [11]. Orcin stains a copper binding protein corresponding to metallothionins. The analysis of homogenized 
tissue, e.g. by atomic absorption spectroscopy [12], can only provide coarse information about the local distribution of these metals in human tissues. Especially, if one is interested in quantitative two-dimensional element mapping in near histological resolution, physical methods such as scanning nuclear microprobes [13], secondary ion mass spectroscopy [14], laser microprobe mass analysis [15], energy-dispersive X-ray analysis [16] have been applied. However, they showed low precision or poor detection limits. Using laser ablation-inductively coupled plasma mass spectrometry an elemental mapping of $\mathrm{Cu}$ and $\mathrm{Zn}$ was achieved in sheep liver slices [17].

The aim of the study was to visualize and quantify the distribution of iron, copper and other elements in human liver slices by microscopic synchrotron radiation X-ray fluorescence analysis ( $\mu$-SRXRF). The microfocus setup at HASYLAB, beamline L, provides a microbeam of $15 \mu \mathrm{m}$ diameter. Twodimensional elemental maps of near histological resolution were recorded and compared with histolochemically prepared samples. The measurement of physiologically relevant areas of some $10 \mathrm{~mm}^{2}$ in reasonable time was facilitated by the implementation of a continuous scanning mode and a new detector system. The investigation of normal liver tissue and cirrhotic hemochromatosis affected liver tissue from a transplanted patient is the first application of the (sub-) second data acquisition setup.

\section{Experimental}

\subsection{Sample system}

Liver slices from a liver transplanted patient (age: 54 years) were investigated. Transplantation had to be performed due to the insufficient liver function caused by liver cirrhosis induced by hemochromatosis. Additionally liver slices from a patient who died from cardio-vascular failure were investigated. Liver sections received from the Pathological Department, Medizinische Universität Wien, were about $10 \mathrm{~cm}^{2}$ in size and imbedded in paraffin. Slices of $10 \mu \mathrm{m}$ thickness were fixed on trace element free Ultralene ${ }^{\circledR}$ foil of $4 \mu \mathrm{m}$ thickness for investigation.

\subsection{Microscopic synchrotron radiation X-ray fluorescence analysis}

Microscopic synchrotron radiation X-ray fluorescence analysis ( $\mu$-SRXRF) measurements were performed at beamline $\mathrm{L}$ of the DORIS III storage ring at HASYLAB/DESY in Hamburg. For details concerning the beamline and standard experimental setup, see Refs. [18,19]. The white beam of the bending magnet was monochromatized by a double multilayer monochromator (NiC). The energy of the incoming beam was set to $17.5 \mathrm{keV}$ for all measurements. The monochromatic $\mathrm{X}$-ray beam was focused by a polycapillary half-lens to a cross section of $15 \mu \mathrm{m}$ providing a flux of $10^{11}$ photons $/ \mathrm{s}[18,20]$. Liver slice samples were mounted on a XYZ-sample stage and scanned relative to the X-ray micro-beam. In the present study a constant sample time of $1.25 \mathrm{~s}$ per point was used. The increment in horizontal direction was $25 \mu \mathrm{m}$ and $15 \mu \mathrm{m}$ in vertical direction. Investigated areas and the position of the measurement were controlled by a long-distance light microscope connected with a CCD camera for controlling areas of interest in an incident- or transmitted light mode. Fluorescence photons and scattered radiation are detected in an energydispersive semiconductor detector. Previous studies on tissue slice samples [21] revealed that the sensitivity of the spectrometer and time of measurement is limited not by the flux of the incoming beam, but by the maximum processable countrate of the X-ray detector and electronics and the overhead time of the motor control system between successive points of the scan. Therefore, the standard setup was modified by the use of a detector collimator designed to reduce air scattering, the replacement of the $\mathrm{Si}(\mathrm{Li})$ detector by a silicon drift detector and the implementation of the continuous scanning mode for the reduction of overhead time.

\subsubsection{Detector collimator}

The collimator has a conical inner shape. Its inner diameter opens from $1 \mathrm{~mm}$ at the tip to $6 \mathrm{~mm}$ close to the detector window. The distance of the collimator tip to the detector crystal is $25 \mathrm{~mm}$. A detector crystal of $50 \mathrm{~mm}^{2}$ area is completely illuminated at a distance of $3 \mathrm{~mm}$ from the sample to the

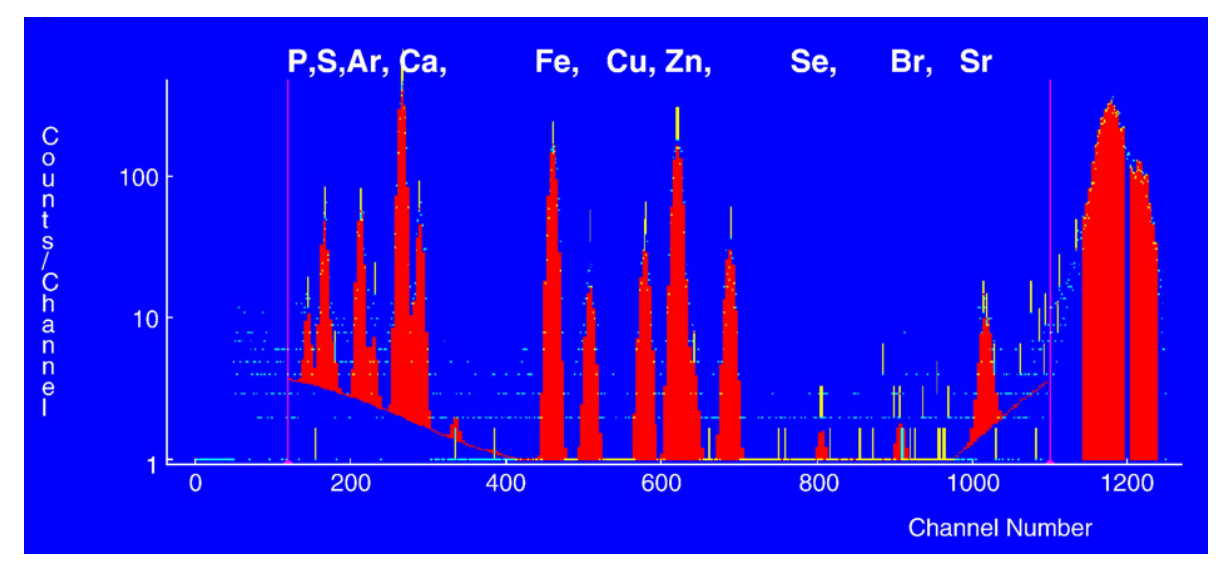

Fig. 1. Single spectrum of normal liver tissue fitted using the AXIL software. Observed elements are P, S, Ar, Ca, Fe, Cu, Zn, Se, Br, Sr. Acquisition time 1.25 s. 
Table 1

Mean values of count rate (cts/s) and concentration (ppm) of elements in normal liver tissue of $10 \mu \mathrm{m}$ thickness after fixation and imbedding in paraffin

\begin{tabular}{lrrrrrrrrl}
\hline Elem & $\mathrm{P}$ & $\mathrm{S}$ & $\mathrm{Ca}$ & $\mathrm{Fe}$ & $\mathrm{Cu}$ & $\mathrm{Zn}$ & $\mathrm{Se}$ & $\mathrm{Br}$ & Comp \\
\hline $\mathrm{Cts} / \mathrm{s}$ & 54.3 & 308 & 3177 & 1475 & 304 & 1868 & 14.3 & 15.1 & 7500 \\
$\mathrm{ppm}$ & 1604 & 2482 & 2287 & 152 & 20.1 & 88.9 & 0.6 & 0.55 & - \\
\hline
\end{tabular}

collimator tip, but sees only $2 \mathrm{~mm}$ air path excited by the incoming beam. The front part facing the detector is made of solid molybdenum of $99.95 \%$ purity (minimum wall thickness of $4 \mathrm{~mm}$ ). The collimator shields the detector crystal also efficiently against fluorescence radiation emitted by the housing of the polycapillary and facilitates contamination-free detection.

\subsubsection{Silicon drift detector}

A silicon multi-cathode X-ray Spectrometer VORTEX-EX (Radiant Detector Technologies) has been employed in combination with a CANBERRA 2060 digital pulse processor. The system provides an excellent energy resolution of $150 \mathrm{eV}$ $(5.8 \mathrm{keV})$ for all count rates up to $80000 \mathrm{cts} / \mathrm{s}$. Shifts in peak position with count rate or other types of instabilities have not been observed [22]. The large active area of $50 \mathrm{~mm}^{2}$ and the detector snout length of $100 \mathrm{~mm}$ enable a solid angle of detection similar to that of a standard $\mathrm{Si}(\mathrm{Li})$ detector.

\subsubsection{Continuous scanning mode}

In the standard scanning mode for the measurement of XRF maps motor movement spectrum acquisition, readout and transfer are executed sequentially, which results in an overhead time of $\sim 2 \mathrm{~s}$ per measurement point at our experiment. Fast scans of (sub-) second time per measurement point are made feasible with the implementation of the continuous scanning mode [23]. The motor of the inner loop is moving continuously with speed $v$ while spectra are collected in the multi channel analyzer (MCA) for a predefined sample time $\Delta t$. During readout of the data and writing the complete MCA spectrum on hard disk the spectrometer is "blind" for a constant time $\delta t$. Time $\Delta t+\delta t$ and speed $\mathrm{v}$ determine the pixel size $\Delta y$. However, for typical values of $1.25 \mathrm{~s}$ sample time and $25 \mu \mathrm{m}$ pixel size the coverage $\Delta t /(\Delta t+\delta t)$ is $98 \%$ and can be neglected. After
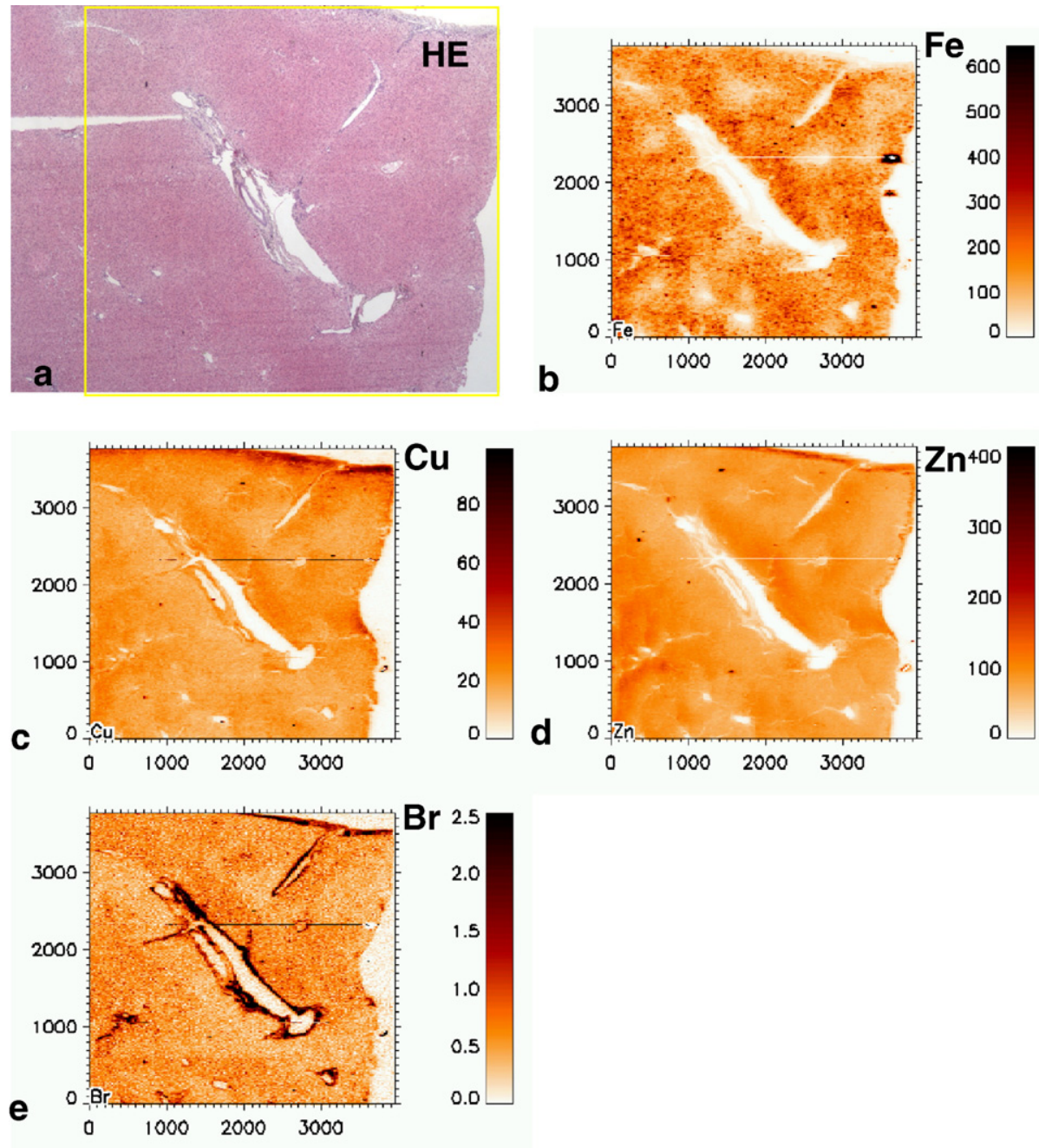

Fig. 2. a-d: Normal liver tissue (20× light microscope) with Hematoxilin-Eosin (HE) staining in comparison with (b) iron (Fe), (c) copper (Cu), (d) zinc (Zn) and (e) bromine $(\mathrm{Br})$ distribution determined by $\mu$-SRXRF. Sample time/pixel $1.25 \mathrm{~s}$, area $4000 \times 3750 \mu \mathrm{m}^{2}, 25 \times 15 \mu \mathrm{m}^{2}$ step size. The color bar at the right indicates the element concentration in ppm. 
completion of a line, the motor moves back with maximum speed, the other motor is moved by one step and the next line is measured. The motor positions, MCA file names, counters for ionization chamber signal, DSP dead time and DORIS current and predefined regions of interest (ROI) of the MCA for every pixel are compiled in a single ASCII file, which is updated after every pixel. This file is also used for the display of the ROI maps during the measurement.

\subsubsection{Quantification}

The X-ray spectra were peak-fitted using the AXIL program package [24], in order to extract the net intensities of fluorescence lines. A typical peak fitted spectrum of normal liver tissue is shown in Fig. 1. The net peak intensities were normalized to the intensity of the incoming monochromatic beam intensity and $1 \mathrm{~s}$ sample time, and were corrected for detector system dead time. A germanium standard foil of homogeneous Ge area density of $2.6 \times 10^{-8} \mathrm{~g} / \mathrm{cm}^{3}$ was employed for external standardization [25]. An array $9 \times 5$ points was measured for $10 \mathrm{~s}$ before and after each $2 \mathrm{~d}$ scan. The standard deviation of the mean Ge K- $\alpha$ line intensity between individual scans was $1.7 \%$ after normalization, demonstrating the stability of the experimental conditions. Element concentrations were calculated from the normalized net peak intensities using the fundamental parameter method based program package "quant" [26]. No absorption correction was necessary for the elements of interest $(Z>25)$ on thin section of organic tissue and the sample-detector geometry, sample thickness and beam energy was unchanged during the measurement series. Therefore, the same set of element specific conversion factors could be applied for all measurements.

\subsubsection{Sensitivity of spectrometer for liver tissue analysis}

The intensity of the micro beam provided by the combination of multilayer monochromator and polycapillary optics and the large solid angle of the detector enable a high sensitivity of the spectrometer for the elements in the range from $\mathrm{P}$ to Sr. Table 1 specifies the mean counts per second net peak intensities and concentrations derived from the fundamental parameter calculations obtained on normal liver tissue of $10 \mu \mathrm{m}$ thickness. The net peak intensities are high enough to realize low-noise element maps for elements like $\mathrm{Fe}$ or $\mathrm{Zn}$, but reasonable structures within 2D mapping can be also obtained for trace elements like $\mathrm{Se}$ and $\mathrm{Br}$ or light elements like $\mathrm{P}$ and $\mathrm{S}$ within $1 \mathrm{~s}$ sample time per pixel, as demonstrated in Figs. 2 and 4.

\section{Results and discussion}

\subsection{Normal liver tissue}

Fig. 2 shows the results of two-dimensional iron (Fig. 2b), copper (Fig. 2c) and zinc mapping (Fig. 2d) in a slice of not affected, normal liver tissue in comparison with a conventional, histological Hematoxylin-Eosin (HE) staining (Fig. 2a). Additionally, the distribution of bromine (Fig. 2e) is given. Bromine seems to be mainly distributed in connective tissue and vessel walls $[27,28]$. In normal liver tissue iron, copper and zinc distributions revealed no greater differences in their concentration throughout the measured area, and varied only in a small range (Fig. 3a-c). However slightly elevated concentrations of $\mathrm{Cu}$ and $\mathrm{Zn}$ were found in the liver capsule (upper border of Fig. 2c, d), which consists mainly of connective tissue as indicated by the increase of bromine (Fig. 2e). Mean values of the investigated elemental concentrations are given in Tab 2. The determined elemental concentrations for $\mathrm{Fe}, \mathrm{Cu}$ and $\mathrm{Zn}$ in normal liver tissue by using a germanium-standard for their calculation were in line with previously published data mostly
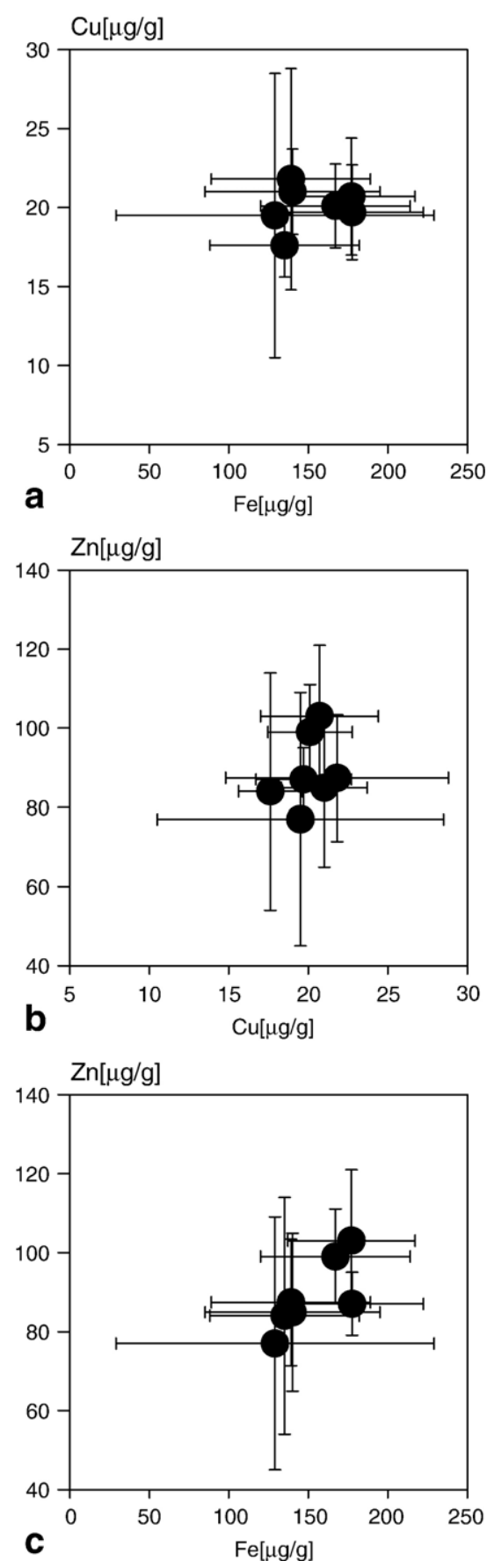

Fig. 3. a-c: Associations between (a) $\mathrm{Fe}$ and $\mathrm{Cu}$, (b) $\mathrm{Cu}$ and $\mathrm{Zn}$ and (c) $\mathrm{Fe}$ and $\mathrm{Zn}$ in normal liver tissue determined for six different areas and total scan, each. Concentrations are given in ppm ( $\mu \mathrm{g} / \mathrm{g}$ sample weight). 

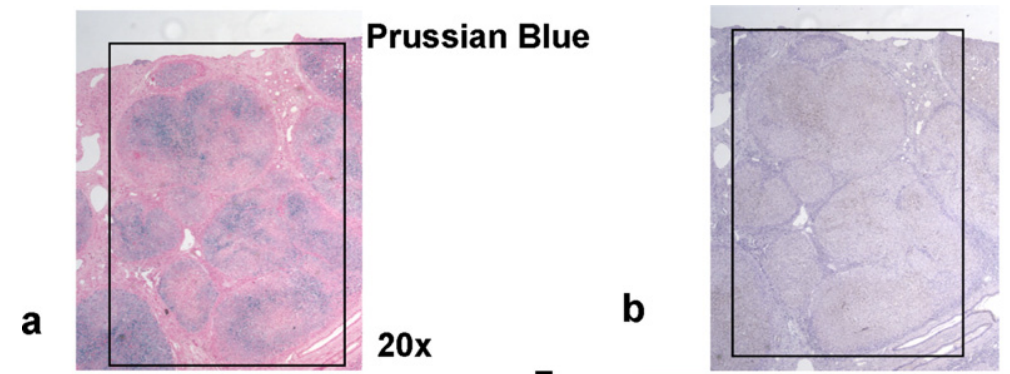

\section{Rhodanine}

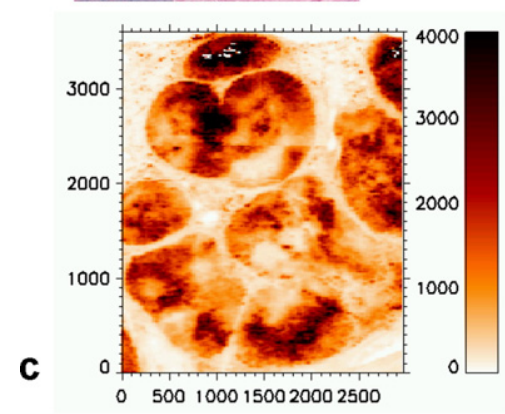

$\mathrm{Fe}$

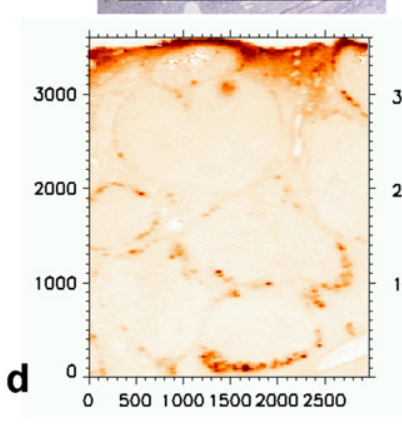

$\mathrm{Cu}$
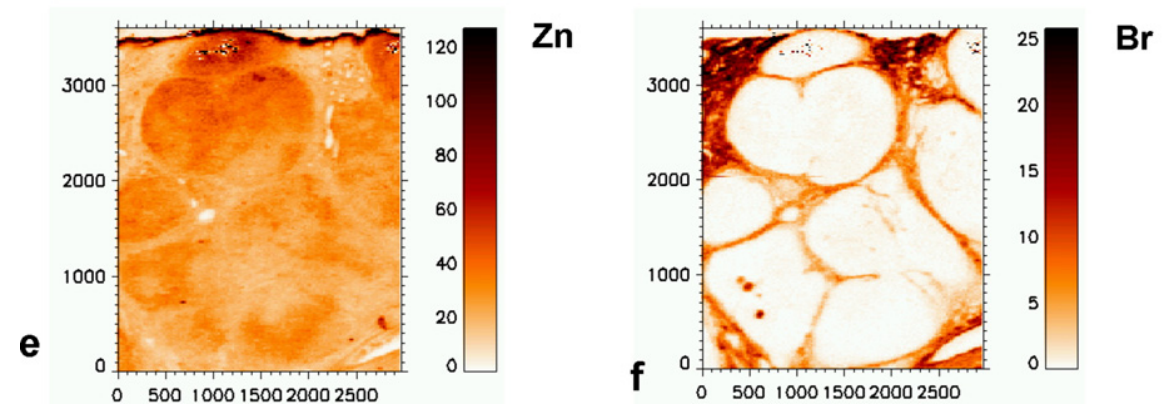

Fig. 4. a-f: Hemachromatosis (HC) with regeneration nodules. (a) Prussian Blue staining, (b) Rhodanine staining (20×, light microscope) and (c) iron (Fe) and (d) copper $(\mathrm{Cu})$ elemental maps determined by $\mu$-SRXRF. Also shown are (e) zinc ( $\mathrm{Zn}$ ) and (f) bromine (Br) elemental maps. Sample time/pixel $1.25 \mathrm{~s}$, area $4000 \times 3750 \mu \mathrm{m}^{2}, 25 \times 15 \mu \mathrm{m}^{2}$ step size. The color bar at the right indicates the element concentration in ppm.

determined by using atomic absorption or X-ray fluorescence techniques $[29,30]$. In normal liver tissue low variations for $\mathrm{Fe}$, $\mathrm{Cu}$ and $\mathrm{Zn}$ were detectable, indicating a close homeostatic balance between these elements. These results are consistent with previously published data in normal liver tissue [29-34].

\subsection{Haemachromatosis}

Two-dimensional scans in a liver slice from a patient with genetically confirmed iron-overload due to a hemochromatosis are shown in Fig. 4a-fin comparison with two different histochemical stainings: Fig. 4a Prussian Blue and Fig. 4b Rhodanine. The cirrhotic nodules are clearly distinguishable not only in the histological preparation but also in the element maps. As seen in Fig. 4a and Fig. 4c an excellent coherence between the histochemical preparation of $\mathrm{Fe}$ and the Fe-element-map was achieved, showing an in-homogenous distribution of Fe within cirrhotic nodules. By contrast, this is not the case for the copper distribution in comparison with the histochemical preparation (Fig. $4 \mathrm{~b}$ and d). Again higher concentrations of $\mathrm{Cu}$ were detected for the liver capsule, but more surprising high concentrations of $\mathrm{Cu}$ were located around the iron-loaded regeneration nodules. Normal concentrations of $\mathrm{Cu}$ existed within the cirrhotic nodules. Again $\mathrm{Br}$ clearly demarcates the regeneration nodules, and characterizes thus the fibrotic connective tissue between them (Fig. 4f). Interestingly, $\mathrm{Cu}$ distribution in $\mathrm{HC}$ turned out to be characteristically distributed in comparison with Fe. Higher concentrations of $\mathrm{Cu}$ at the border of the Fe containing regeneration nodules were found (Fig. 4d). Inspecting the corresponding histological preparation in a higher magnification $(50 \times)$, this border area is characterized by a zone of lymphocyte infiltration. We therefore may suspect that the higher $\mathrm{Cu}$ concentration is associated with these cells. Copper metabolism is altered in inflammation. In contrast to iron levels that decline in serum in infection and inflammation, copper concentration rise. Moreover, copper-containing enzymes and even many copper complexes are capable of protecting against the organism radical oxygen species in chronic diseases [2], and may thus give a clue for the observed increased copper levels at the border of the Fecontaining regeneration nodules.

Table 2

Mean values and S.D. for determined elements in normal liver tissue (NL) and for liver tissue in hemochromatosis (HC) given in ppm ( $\mu \mathrm{g} / \mathrm{g}$ sample weight)

\begin{tabular}{llrrrrrr}
\hline ppm & & \multicolumn{1}{c}{$\mathrm{P}$} & \multicolumn{1}{c}{$\mathrm{S}$} & \multicolumn{1}{c}{$\mathrm{Ca}$} & \multicolumn{1}{c}{$\mathrm{Fe}$} & \multicolumn{1}{c}{$\mathrm{Cu}$} & \multicolumn{1}{c}{$\mathrm{Zn}$} \\
\hline $\mathrm{NL}$ & Mean & 1604 & 2482 & 2287 & 152 & 20.1 & 88.9 \\
& S.D. & 511 & 457 & 394 & 54 & 4.3 & 19.5 \\
$\mathrm{HC}$ & Mean & 801 & 1115 & 1390 & 1102 & 35.9 & 27.2 \\
& S.D. & 307 & 243 & 261 & 539 & 14.6 & 6.7 \\
\hline
\end{tabular}



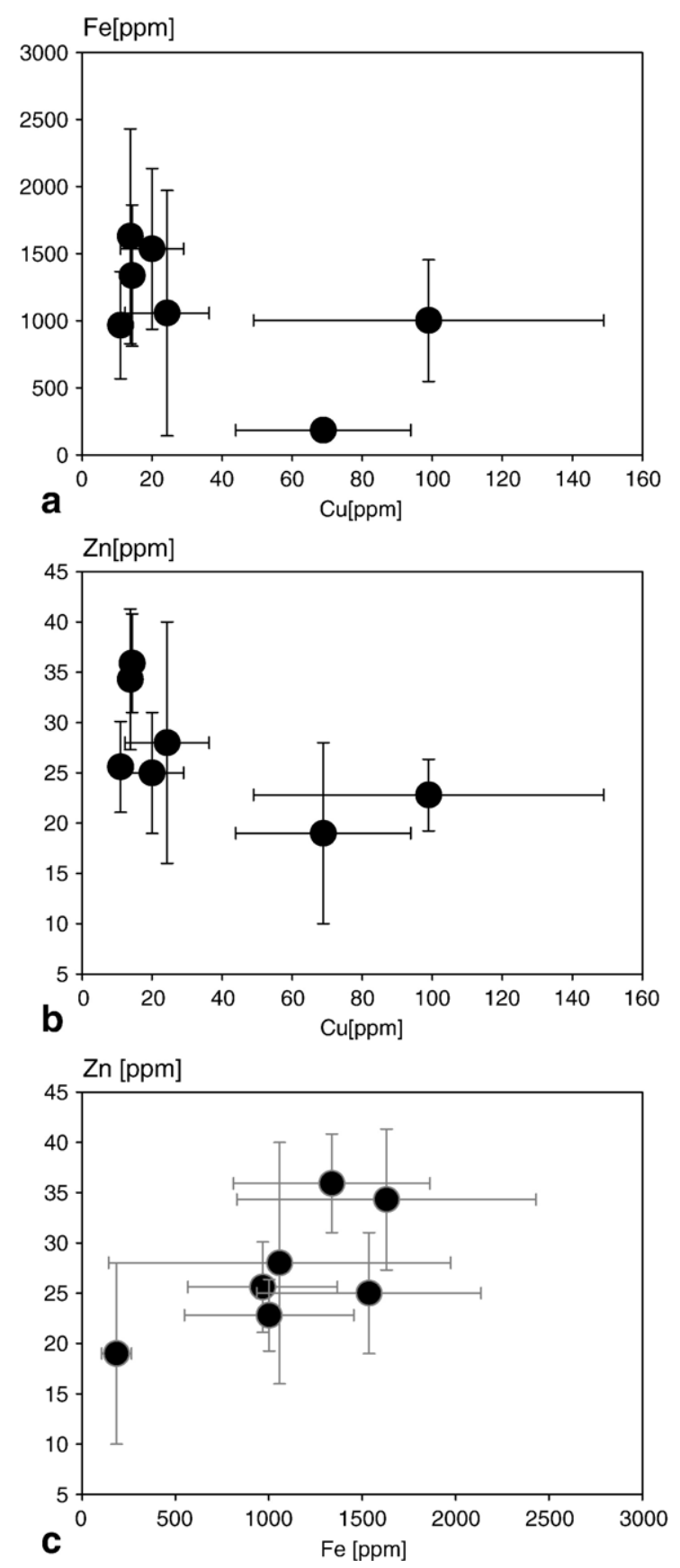

Fig. 5. a-c: Associations between (a) $\mathrm{Fe}$ and $\mathrm{Cu}$, (b) $\mathrm{Cu}$ and $\mathrm{Zn}$ and (c) $\mathrm{Fe}$ and $\mathrm{Zn}$ in hemochromatosis (HC) normal liver tissue determined for five different areas and total scan, each. Concentrations are given in $\mathrm{ppm}(\mu \mathrm{g} / \mathrm{g}$ sample weight).

In Table 2 values for the concentrations are given, determined as stated above. Interestingly $\mathrm{P}, \mathrm{S}, \mathrm{Ca}$ and $\mathrm{Zn}$ were significantly reduced, while $\mathrm{Cu}$ was increased as it was the expected case for Fe. Scarce information is available about sulphur and phosphorus concentrations in HC. Quantitative hepatic phosphorus-32 magnetic resonance spectroscopy investigations in liver cirrhosis indicate that particular in decompensated liver cirrhosis metabolic disturbances in hepatic energy and phospholipids metabolism exist. A significantly decreased level of adenosine-tri-phosphate was found $[39,40]$.
On the other hand, recent findings indicate that sulphurcontaining amino acids attenuate the development of liver fibrosis [41]. In the light of these findings the decreased phosphorus and sulphur level in our HC measurements seems to be feasible. However, for comparison of absolute concentration values with other studies it should be noticed that the samples used in our study were chemically fixated and embedded in paraffin. It is known that this preparation can change the concentration of light elements significantly [42]. Potassium, for example, is almost completely eliminated.

\subsection{Elemental dependencies}

As suspected from Fig. 3 an inverse dependency between $\mathrm{Fe}$ and $\mathrm{Cu}$ distribution seems to exist in $\mathrm{HC}$. In Fig. $5 \mathrm{a}-\mathrm{c}$ this is demonstrated numerically. A high $\mathrm{Fe}$ concentration in liver tissue is associated with a decrease of the $\mathrm{Cu}$ (Fig. 5a). Moreover high $\mathrm{Cu}$ decreases $\mathrm{Zn}$ (Fig. 5b) while Fe and $\mathrm{Zn}$ are positively correlated (Fig. 5c). Metabolic links between $\mathrm{Fe}, \mathrm{Cu}$ and $\mathrm{Zn}$ have been repeatedly described on the molecular basis [1]. Their interaction was found in processes such as Fe uptake in eukaryotes, ceruloplasmin ferroxidase activity [35] or metallothionein (MT) induction. MT is a cysteine-based protein that transports metals such as $\mathrm{Cu}$ and $\mathrm{Zn}$. The recently described divalent metal transporter (DMT1) binds not only Fe but also $\mathrm{Cu}$ [36-38]. These biochemical dependencies should be elucidated by inspecting and analysing regions with different $\mathrm{Fe}$ concentrations in the scans of HC. In fact, correlations between $\mathrm{Fe}, \mathrm{Cu}$ and $\mathrm{Zn}$ were found (Fig. $5 \mathrm{a}-\mathrm{c}$ ). While a negative correlation was found for $\mathrm{Cu}-\mathrm{Fe}$ and $\mathrm{Cu}-\mathrm{Zn}$, a positive one existed for $\mathrm{Fe}-\mathrm{Zn}$. This seems to correspond with recent findings. Exposing Hep-G2 cells - a model of hepatic cells - to increasing extracellular $\mathrm{Cu}$ concentrations resulted in a decrease of $\mathrm{Fe}$ and $\mathrm{Zn}$ concentration intracellular, measuring $\mathrm{Fe}$ and $\mathrm{Zn}$ contents by total-reflection X-ray fluorescence spectrometry [38]. These data indicate that $\mathrm{Cu}$ overload at least in Hep-G2 cell lines reduces their $\mathrm{Fe}$ and $\mathrm{Zn}$ content presumably by downregulating DMT1 activity. Our investigated sample was a genetically caused hemochromatosis. But it seems at present that high Fe reduces $\mathrm{Cu}$ and increases $\mathrm{Zn}$ in liver tissue in $\mathrm{HC}$.

\section{Conclusion}

In conclusion we could demonstrate that using SRXRF technique with a focal beam size diameter of $15 \mu \mathrm{m}$ metal distributions in a near histological resolution can be achieved. The spatial resolution approximately corresponds to a 20 times magnified histologic preparation so that elemental distribution can be associated to structural differences. In determining elemental concentrations additionally metabolic links between $\mathrm{Fe}, \mathrm{Cu}$ and $\mathrm{Zn}$ could be calculated which seem in line with biochemical investigations.

\section{Acknowledgments}

We thank J. Feuerborn and J. Broekaert, Institut für Anorganische und Angewandte Chemie, Universität Hamburg, 
for providing the germanium standard sample and the RADIANT VORTEX detector, respectively.

\section{References}

[1] R.R. Crichton, S. Wilment, R. Legssyer, R.J. Ward, Molecular and cellular mechanisms of iron homeostasis and toxicity in mammalian cells, J. Inorg. Biochem. 25 (2002) 9-18.

[2] H. Tapiero, D.M. Townsend, K.D. Tew, Trace elements in human physiology and pathology, Copper, Biomed. Pharmacother. 57 (2003) 386-398.

[3] E.D. Harris, The iron-copper connection: the link to ceruloplasmin grows stronger, Nutr. Rev. 53 (1995) 170-1733.

[4] E.D. Harris, Basic and clinical aspects of copper, Crit. Rev. Clin. Lab. Sci 40 (2003) 547-586.

[5] P.L. Fox, The copper-iron chronicles: the story of an intimate relationship, Biometals 16 (2003) 9-40.

[6] R.S. Ajioka, J.P. Kushner, Hereditary hemochromatosis, Semin. Hematol. 39 (2002) 235-241.

[7] V. Medici, G.C. Sturniolo, A. Santon, R. D'Inca, M. Bortolami, R. Cardin, D. Basso, V. Albergoni, P. Irato, Efficacy of zinc supplementation in preventing acute hepatitis in Long-Evans Cinnamon rats, Liver Int. 25 (2005) 888-895.

[8] A.S. Tavill, Diagnosis and management of hemochromatosis, Hepatology 33 (2001) 1321-1328.

[9] L. Pilloni, S. Lecca, P. Van Eyken, C. Flore, L. Demelia, G. Pilleri, A.M. Nurchi, A.M. Farci, R. Ambu, F. Callea, G. Faa, Value of histochemical stains for copper in the diagnosis of Wilson's disease, Histopathology 33 (1998) 28-33.

[10] S. Lecca, L. Pilloni, R. Ambu, C. Flore, F. Callea, G. Faa, Multiple histochemical methods in the diagnosis of Wilson's disease. Presentation of 74 cases and review of the literature, Pathologica 90 (1998) 771-775.

[11] I.C. Fuentealba, S. Haywood, J. Trafford, Evaluation of histochemical methods for the detection of copper overload in rat liver, Liver 7 (1987) 277-282.

[12] R.G. Treble, T.S. Thompson, H.R. Lynch, Determination of copper, manganese and zinc in human liver, Biometals 11 (1998) 49-53.

[13] F. Watt, Nuclear microscope analysis in Alzheimer's and Parkinson's disease: A review, Cell Mol. Biol. (Noisy-le-grand) 42 (1996) 17-26.

[14] P.J. Todd, T.G. Schaaff, P. Chaurand, R.M. Caprioli, Organic ion imaging of biological tissue with secondary ion mass spectrometry and matrix-assisted laser desorption/ionization, J. Mass Spectrom. 36 (2001) 355-369.

[15] T.C. Iancu, D.P. Perl, I. Sternlieb, A. Lerner, E. Leshinsky, E.H. Kolodny, A. Hsu, P.F. Good, The application of laser microprobe mass analysis to the study of biological material, Biometals 9 (1996) 57-65.

[16] K. Watanabe, O. Miyakawa, M. Kobayashi, New method for quantitative mapping of metallic elements in tissue sections by electron probe microanalyser with wavelength dispersive spectrometers, J. Electron. Microsc. (Tokyo) 50 (2001) 77-82.

[17] A. Kindness, C.N. Sekaran, J. Feldmann, Two-dimensional mapping of copper and zinc in liver sections by laser ablation-inductively coupled plasma mass spectrometry, Clin. Chem. 49 (2003) 1916-1923.

[18] G. Falkenberg, Th. Tschentscher, O. Clauss, X-ray optics for the microfocus beamline L, In Hasylab Annual Report 2001; www.hasylab. desy.de/science/annual_reports/2001_report/part1/intern/5720.pdf.

[19] G. Falkenberg, K. Rickers, Pink-beam and monochromatic X-ray fluorescence analysis at the beamline L, In Hasylab Annual Report 2002; www.hasylab.desy.de/science/annual_reports/2002_report/part1/intern/ 8522.pdf.

[20] K. Proost, L. Vincze, K. Janssens, N. Gao, E. Bulska, M. Schreiner, G. Falkenberg, Characterization of a polycapillary lens for use in microXANES experiments, X-ray Spectrom. 32 (2003) 215-222.

[21] M. Kühbacher, G. Weseloh, A. Thomzig, J. Kneipp, M. Beekes, G. Falkenberg, M. Radtke, H. Riesemeier, A. Kyriakopoulos, D. Behne, Analysis and location of metal- and metalloid-containing proteins by synchrotron radiation X-ray fluorescence spectrometry, X-ray Spectrom. 34 (2005) 112-117.
[22] G. Falkenberg, Characterization of a Radiant Vortex Silicon Multi-Cathode $\mathrm{X}$-ray Spectrometer for (total reflection) X-ray fluorescence applications, In Hasylab Annual Report 2005; www.hasylab.desy.de/science/annual reports/2005_report/part1/contrib/49/15255.pdf.

[23] G. Falkenberg, T. Kracht, M. Kühbacher, Fast X-ray fluorescence imaging in continuous scanning mode at beamline L, In Hasylab Annual Report 2005; www.hasylab.desy.de/science/annual_reports/2005_report/part1/ contrib./25/15448.pdf.

[24] B. Vekemans, K. Janssens, L. Vincze, F. Adams, P. van Espen, Comparison of several background compensation methods useful for evaluation of energy-dispersive X-ray fluorescence spectra, Spectrochim. Acta Part B 50 (1995) 149-169.

[25] J. Feuerborn, A. Knöchel, A-K. Meyer, F. Lechtenberg, G. Falkenberg, K. Rickers, Sputtered Germanium Films as an Internal Standard for Quantitative X-ray Fluorescence Analysis of Thin Film Samples, In Hasylab Annual Report 2002, www.hasylab.desy.de/science/annual reports/2002 report/part1/contrib/47/7296.pdf.

[26] Vincze L, Univ. Ghent, Belgium, private communication.

[27] N. Zöger, P. Wobrauschek, C. Streli, G. Pepponi, P. Roschger, G. Falkenberg, W. Osterode, Distribution of $\mathrm{Pb}$ and $\mathrm{Zn}$ in slices of human bone by synchrotron $\mu$-XRF, X-ray Spectrom. 34 (2005) 140-143.

[28] N. Zöger, C. Streli, P. Wobrauschek, C. Jokubonis, G. Pepponi, P. Roschger, S. Bohic, W. Osterode, Elemental mapping in slices of human brain by SR-mu XRF, Powder Diffr. 20 (2005) 158-160.

[29] N. Milman, J. Laursen, J. Podenphant, S. Asnaes, Trace elements in norma and cirrhotic human liver tissue, I. Iron, copper, zinc, selenium, manganese, titanium and lead measured by X-ray fluorescence spectrometry, Liver 6 (1986) 111-117.

[30] N. Milman, J. Laursen, J. Podenphant, P. Staun-Olsen, Iron, copper, zinc and selenium in human liver tissue measured by X-ray fluorescence spectrometry, Scand. J. Clin. Lab. Invest. 43 (1983) 691-697.

[31] J.P. Beilby, A.W. Prins, N.R. Swanson, Determination of hepatic iron concentration in fresh and paraffin-embedded tissue, Clin. Chem. 45 (1999) 573-574.

[32] J.K. Olynyk, R. O’Neill, R.S. Britton, B.R. Bacon, Determination of hepatic iron concentration in fresh and paraffin-embedded tissue: diagnostic implications, Gastroenterology 106 (1994) 674-677.

[33] K.L. Nuttall, J. Palaty, G. Lockitch, Reference limits for copper and iron in liver biopsies, Ann. Clin. Lab. Sci. 33 (2003) 443-450.

[34] E.M. Brunt, J.K. Olynyk, R.S. Britton, C.G. Janney, A.M. Di Bisceglie, B.R. Bacon, Histological evaluation of iron in liver biopsies: relationship to HFE mutations, Am. J. Gastroenterol. 95 (2000) 1788-1793.

[35] E.D. Harris, Zinc and copper: evidence for interdependence, no antagonism, Nutrition 17 (2001) 734.

[36] M.D. Garrick, M.T. Nunez, M. Olivares, E.D. Harris, Parallels and contrasts between iron and copper metabolism, Biometals 16 (2003) 1-8.

[37] M. Arredondo, P. Munoz, C.V. Mura, M.T. Nunez, DMT1, a physiologically relevant apical $\mathrm{Cu} 1+$ transporter of intestinal cells, Am. J. Physiol., Cell Physiol. 284 (2003) C1525-C1530.

[38] M. Arredondo, V. Cambiazo, L. Tapia, M. Gonzalez-Aguero, M.T. Nunez, R. Uauy, M. Gonzalez, Copper overload affects copper and iron metabolism in Hep-G2 cells, Am. J. Physiol.: Gastrointest. Liver Physiol. 287 (2004) G27-G32.

[39] J.D. Bell, K.K. Bhakoo, Metabolic changes underlying 31P MR spectral alterations in human hepatic tumours, NMR Biomed. 11 (1998) 354-359.

[40] I.R. Corbin, L.N. Ryner, H. Singh, G.Y. Minuk, Quantitative hepatic phosphorus-31 magnetic resonance spectroscopy in compensated and decompensated cirrhosis, Am. J. Physiol.: Gastrointest. Liver Physiol. 287 (2004) G379-G384

[41] H. Matsui, K. Ikeda, Y. Nakajima, S. Horikawa, Y. Imanishi, N. Kawada, Sulfur-containing amino acids attenuate the development of liver fibrosis in rats through down-regulation of stellate cell activation, J. Hepatol. 40 (2004) 917-925.

[42] J. Chwiej, M. Szczerbowska-Boruchowska, M. Lankosz, S. Wojcik, G. Falkenberg, Z. Stegowski, Z. Setkowicz, Preparation of tissue samples for X-ray fluorescence microscopy, Spectrochim. Acta Part B 60 (2005) $1531-1537$ 